\title{
KONSTRUKSI SOSIAL-TEOLOGIS RITUAL IJAZAH ASMA' ARTHO (UANG AZIMAT) DI PONDOK PESANTREN FATHUL ULUM KWAGEAN PARE KEDIRI
}

\author{
Mukhammad Zamzami \\ Universitas Islam Negeri Sunan Ampel Surabaya, Indonesia \\ E-mail: mukhammadzamzami@gmail.com
}

\begin{abstract}
This article scrutinizes social and theological constructions of the practice of ijazah Asma' Artho or Uang Azimat (money blessing tradition) in Fathul Ulum Islamic Boarding School. Asma' Artho is not a practice of doubling money. It is only money blessed by kiai. There is a symbol contained in the post-blessing money, the kiai, through his team, writes the word Bäsit, one of Asmä' al-Husnā, on the blessed money. Socially, the practice, which is routinely implemented every year, is not only sought by the santri, but also the general public and businessmen. If santri and the general public wishes the blessing of their rejection from this ritual process, then it is different from the perspective of the business community, where they believe this money (Asma' Artho) has enough impact on the increase in the business's current good. For them, the more blessed the money is, the more fortune it earns. In understanding the theological construct of this blessed money, the author examines the meaning of the Bäsit, one of Asmà' al-Husnā, and the interpretation of this word in the Qur'an which is contained in the money and how to read the rajah. This bleesed money is based on the thought of Abū Hāmid al-Ghazālī, Abū Bakr Muhammad Shatā al-Dimyātī, and Ma'rūf al-Karkhī. AlKarkhī said has even said that anyone who reads the mawlid upon the Prophet Muhammad on some silver or gold-plated dirhams and then mix the dirhams with other dirhams, these dirhams will then get a blessing.
\end{abstract}

Keywords: Social constructions; theological constructions; Asma' Artho; Asmāò al-Husnā.

\section{Pendahuluan}

Dunia ekonomi Jawa terkadang memang berbau sakral. Tak sedikit para pelaku ekonomi yang melakukan mistik kejawen dalam 
rangka mencari pelarisan (agar dagangan laris terjual) dan golek pesugihan (mencari kekayaan). Dua tradisi ini ditempuh melalui ragam ritual mistik kejawen yang khusyuk. Mereka senang mendatangi tempattempat keramat yang dianggap memiliki tuah. Beberapa tempat yang sering didatangi pelaku ekonomi Jawa antara lain di gunung Kemukus di Sragen, ${ }^{1}$ gunung Srandhil di Cilacap, ${ }^{2}$ gunung Kawi di Malang, ${ }^{3}$ Makam Sewu, Parangtritis, dan sebagainya. Tempat-tempat tersebut dipandang akan memberi tuah bagi kekayaan seseorang.

Di tempat-tempat keramat tersebut, biasanya terdapat makam leluhur yang pantas dimintai tolong agar dirinya kaya atau ekonominya lancar. Yang dilakukan di tempat itu adalah berdoa, nyekar, dan bersemedi agar diberi kemudahan melaksanakan ekonomi. Dalam riset yang dilakukan oleh Suwardi Endraswara yang meriset pelaku ekonomi Jawa yang datang dari Salatiga ke gunung Kemukus ditegaskan bahwa pelaku tersebut merasa bangkrut saat menjalankan usaha toko. Ia kemudian datang ke makan Pangeran Samodra dan Sendang Ontrowulan di gunung Kemukus. Di sana ia benar-benar meminta dengan cara bersemedi, mengambil bunga-bunga yang tersebar di atas makam, dan membasuh mukanya di Sendang

1 Ziarah pada makam Pangeran Samudro dianggap sebagai ritual mistis yang disalahgunakan menjadi tempat ritual pesugihan yang disertai dengan hubungan seks dengan non-mahram sebagai syarat agar segala permintaan atau keinginan peziarah dapat dikabulkan. Lihat Rika Devi Novitasari, "Ritual Ziarah Makam Pangeran Samudro di Gunung Kemukus Desa Pendem, Kecamatan Sumberlawang, Kabupaten Sragen" (Skripsi--Universitas Negeri Semarang, 2015). Bandingkan dengan temuan Nurul Azizah, "Persepsi Masyarakat, Tata Cara, dan Dampak Ritual Ngalap Berkah pada obyek wisata Gunung Kemukus Kabupaten Sragen" (Skripsi-Universitas Muhammadiyah Surakarta, 2014).

2 Yudha Irawan, V. Indah Sri Pinasti, dan Puji Lestari, "Fenomena Bersemedi di Tempat Petilasan Sekitar Gunung Srandil, Adipala, Cilacap, Jawa Tengah", ESocietas, Vol. 4, No. 6, (2015).

${ }^{3}$ Secara historis, Zamhari mendapati bahwa Pesarean Gunung Kawi memiliki latar belakang makam Eyang Djoego dan Raden Mas Iman Soedjono. Kedua tokoh ini adalah mantan pasukan dan orang terdekat Pangeran Diponegoro yang lari ke wilayah Jawa bagian Timur setelah kalah pada Perang Jawa. Kedua tokoh ini selama hidupnya sering membantu masyarakat dan menyebarkan Islam, hingga sampai kematiannya karisma mereka masih melekat dengan bukti banyaknya peziarah yang datang ke Pesarean Zamhari. Zamhari Prastyo Hadi, "Fenomena Pesugihan di Pesarean Gunung Kawi Kecamatan Wonosari Kabupaten Malang dan Muatan Pendidikannya" (Skripsi--Universitas Negeri Malang, 2014). 
Ontrowulan. Tak dinyana sedikit demi sedikit usahanya mulai bangkit lagi dan mendapat keuntungan lumayan. ${ }^{4}$

Agaknya fenomena ini mempertegas teori James George Frazer yang menyatakan bahwa pada mulanya manusia merasionalkan pemecahan problem hidupnya. Namun sistem pengetahuan manusia yang terbatas terkadang membuatnya tak sanggup lagi mengelola dengan baik masalah yang dihadapi. Karenanya, mereka menggunakan opsi lain dengan menggunakan magic, ilmu gaib. Magic adalah semua tindakan manusia mencapai sesuatu dengan menggunakan ragam kekuatan alam dan luar lainnya. ${ }^{5}$

Pendek kata, mencari pesugihan dalam masyarakat mistik kejawen memang fenomena unik. Mereka mencari keheningan dan ketenangan batin agar ada koreksi diri dan refleksi ke depan untuk bisnisnya. Bahkan, seringkali mereka menggunakan jimat atau azimat (benda keramat) untuk mendapatkan kekayaan. Tak sedikit pedagang di pasar tradisional Jawa-misalkan di pasar Sepanjang Sidoarjo-yang menggunakan jimat agar dagangannya laris. Jimat tersebut berasal dari tempat keramat, antara lain berupa bunga kenanga, batu akik, keris kecil, dan lain-lain yang diletakkan di bawah barang dagangannya agar menarik pembeli. Jimat tersebut selalu dibubuhi kemenyan setiap malam Jumat dan diberi sesaji ragam bunga. ${ }^{6}$

Pelaku ekonomi Jawa juga sering menjalankan tirakat agar dagangannya laris. Tirakat adalah laku spiritual Jawa yang dilakukan dengan cara sesirik (mencegah sesuatu). Tirakat juga sering dilakukan di rumah saja dan atau di tempat lain yang keramat. Jika dilakukan di rumah, biasanya berpa tapa ngebleng tiga hari tiga malam, berdiam diri di kamar. Tentu saja hal ini akan merugikan dari aspek ekonomi, karena ia tak bisa berjualan. Namun mereka meyakini meskipun harus libur berdagang tiga hari, setelah itu akan mendapatkan keuntungan berlipat. Setidaknya, dagangan mereka akan menarik di mata pembeli.

Berbeda dengan fenomena pesugihan yang sarat dengan tradisi animis sebagaimana yang tergambar di atas, di Pondok Pesantren Fathul Ulum di daerah Kwagean Pare terdapat pemberian ijazah Asma' Artho; sebuah pelestarian tradisi Islam yang sudah mengeliminir tradisi animis dalam ritualnya. Tradisi yang diinisiasi oleh sang pendiri

4 Suwardi Endraswara, Mistik Kejawen: Sinkretisme, Simbolisme, dan Sufisme dalam Budaya Spiritual Jawa (Yogyakarta: Narasi, 2003),

${ }^{5}$ Koentjaraningrat, Sejarah Teori Antropologi (Jakarta: UI Press, 1987).

${ }^{6}$ Observasi di Pasar Sepanjang Sidoarjo 15 Maret 2016. 
pesantren, Kiai Abdul Hannan, lestari dan istikama selama puluhan tahun dilaksanakan pada malam bulan kelahiran Nabi Muhammad. Tradisi ini menggunakan pemakaian simbol-simbol yang disematkan dalam uang itu. Simbol yang tertuang dalam uang tersebut memiliki makna khusus, yang barangkali bisa dianggap sebagai upaya menarik rejeki (jalb al-rizq).

Artikel ini mengupas tentang konstruksi sosial dan teologis tradisi ijazah Asma' Artho, di mana akan diungkap respons masyarakat terhadap ijazah pengasamaan uang ini. Selain itu, penulis mengulas juga dasar-dasar argumentasi keislaman yang dijadikan fondasi praktik ini. Praktik ini cukup signifikan diulas lebih komprehensif, karena tahun 2016 panitia penyelenggara telah meng-asma-i sekira 300.000.000 juta rupiah, baik itu uang umum (uang yang disediakan oleh panitia) atau khusus (uang titipan masyarakat yang mau diasmai uangnya). Biasanya uang khusus adalah uang asing, paralel seri nomor uangnya atau uang yang dianggap istimewa oleh pemiliknya semisal uang yang akan dibuat mahar, dan harus di-asma-i dulu. ${ }^{7}$

\section{Profil Pondok Pesantren Fathul Ulum Kwagean Pare dan Biografi Kiai Abdul Hannan}

\section{A. Profil Pondok Pesantren Fathul Ulum}

Pondok Pesantren Fathul Ulum ini didirikan pertama kali tahun 1981. Asas pesantren ini adalah Pancasila, sedangkan paham ideologi pesantren adalah akidah Ahl al-Sunnah wa al-Jamā'ah. Pesantren ini beralamatkan Jl. Pare Kandangan, Kwagean, Krenceng, Kepung, Krenceng, Kepung, Kediri, Jawa Timur 64293. ${ }^{8}$

Miftahul Ulum adalah nama awal pondok pesantren, di mana saat ini nama tersebut sudah berganti menjadi Fathul Ulum. Penyematan kata Miftäh_-yang berarti kunci-pada pesantren ini karena pesantren adalah pesantren pertama di Kwegean, sedangkan penyematan kata "Ulum" konon diambilkan dari Pondok Pesantren Roudlotul Ulum di Kencong Kediri sebagai wujud tabarrukan Kiai Hannan pada pesantren sang guru, Kiai Ahmadi dan Kiai Zamroji Syaerozi. Dikarenakan terdapat kesamaan nama dengan Miftahul Ulum yang terletak di Jombangan Pare Kediri, pada perkembangan-nya nama pesantren tersebut kemudian diganti menjadi Fathul Ulum. ${ }^{9}$

\footnotetext{
${ }^{7}$ Observasi di Pondok Pesantren Fathul Ulum Kwagean Pare 18 November 2016.

${ }^{8}$ Buku Alumni Pondok Pesantren Fathul Ulum Kwagean Pare, 2016.

${ }^{9}$ Ibid.
} 
Nama Fath yang menjadi awal dari nama pesantren ini tidak jauh berbeda dengan salah satu nama pesantren tempat Kiai Hannan belajar, yakni Pondok Pesantren Futuhiyyah di Mranggen Demak. Kedua pesantren sama-sama menggunakan kata dasar $f-t-h$. Konon, kesamaan ini juga dianggap sebagai tabbarukan kepada pesantren Futuhiyyah di bawah asuhan Kiai Muslih b. Abdurrahman selain nama ini juga direstui oleh sang guru saat melakukan istikhärah penamaan pesantren. ${ }^{10}$

Pesantren Fathul Ulum merupakan lembaga pendidikan Islam berpaham Ahl al-Sunnah wa al-Jamā'ah dengan menyelenggarakan program-program pendidikan madrasah formal dan non-formal, pengajian, kursus-kursus, dan pelatihan serta kegiatan-kegiatan keagamaan serta sosial kemasyarakatan.

\section{B. Sketsa Biografis Kiai Abdul Hannan}

Kiai Abdul Hannan dilahirkan di desa Boto Putih Kecamatan Canggu, $\pm 5 \mathrm{~km}$ sebelah utara dusun Kwagean dari pasangan $\mathrm{Ma}$ 'shum dan Siti Nu'amah. Ia putra keempat dari 12 bersaudara. Ayahnya seorang buruh tani dan penjual kelapa. Sedangkan ibunya adalah adalah seorang penjahit dan juga berjualan jajanan di pasar. Hannan kecil berkembang di lingkungan yang cukup sederhana. Ia rela menjadi buruh dengan menanam singkong di kebun orang lain dengan upah beberapa singkong saja. Hal ini dilakukannya hingga ia tamat dari Sekolah Rakyat. ${ }^{11}$

Saat kecil, Hannan dikenal sosok yang tekun, tawädu', dan mulia. Pada saat berinteraksi dengan masyarakat, ia selalu menggunakan tutur kata halus (Kromo Inggil), hingga semua orang mengenali kekhasan cara bertuturnya. Tidak seperti kebanyakan anak kecil yang suka bermain, ia kecil lebih suka membantu orang tua dengan menggembala kambing dan memelihara hewan peliharaan, seperti itik, ayam, burung, dan lain-lain.

Kiai Hannan mengawali pendidikannya dengan menamatkan pelajarannya di Sekolah Rakyat (sekarang SD). Ia kemudian melanjutkan pendidikannya ke Madrasah Wajib Belajar (MWB) sampai tingkat Madrasah Tingkat Tinggi (MTT). Sekira umur 12 tahun, Kiai Hannan memasuki pendidikan di Pondok Pesantren Roudlotul Ulum Kencong (sebelah Timur wilayah Kwagean) yang

\footnotetext{
${ }^{10}$ Ibid.

${ }^{11}$ Ibid.
} 
diasuh oleh KH. Ahmadi dan KH. Zamroji Syaerozi. Sekira 15 tahun ia menghabiskan waktu di pondok pesantren ini. Sebelum belajar di Pesantren tersebut, Hannan muda memang sudah cukup akrab dengan tradisi pembelajaran ala pesantren di desanya. Ia pun sudah menamatkan belajar kitab Sullam al-Tawfiq dan bahkan sudah menghafal tasrif istilähì dan lughawi ${ }^{-12}$

Selama menuntut ilmu, Kiai Hannan belajar kepada beberapa kiai, antara lain: Kiai Ahmadi (Kencong, Kediri), Kiai Zamroji Syaerozi (Kencong, Kediri), Kiai Mahrus Ali (Lirboyo, Kediri), Kiai Maimun bin Kiai Zubair (Sarang, Jawa Tengah), Kiai Muslih (Mranggen, Jawa Tengah), Kiai Jamaluddin (Batokan, Kediri), Kiai Jauhari Umar (Pasuruan), Kiai Dimyati (Kaliwungu, Kendal), dan lain-lain. ${ }^{13}$ Dalam sanad keilmuan, Kiai Hannan pernah mendapatkan ijazah dari shaykh Yasin al-Fadani saat berkunjung ke Pondok Pesantren Hidayatul Mubtadiin Lirboyo Kediri sekira tahun 1982. Bahkan ditegaskan oleh Kiai Hannan, bahwa saat beliau menerima ijazah sanad keilmuan dari shaykh Yasin, saat itu beliau tidak banyak mempunyai kitab-kitab yang diijazahi. Akan tetapi beberapa waktu yang tidak lama pasca-ijazah, kitab-kitab yang diijazahkan datang pada beliau dari banyak sumber yang tak terduga. ${ }^{14}$

Adapun beberapa santri yang pernah berguru kepada Kiai Hannan, antara lain: Kiai Mohammad Hadi Mahfud (Mlaten, Tulungagung), KH. Mas'ud (Gondang, Blitar), Kiai Saiful Bahri (Blitar), Kiai Imam Mawardi (Blitar), Kiai Yahya (Medini, Kudus), Kiai Agus Mas'ud (Banyuwangi), Kiai Abdul Halim (Banyuwangi), Kiai Ahmad Rafici (Pekalongan), Gus Wahab (Tambak Beras, Jombang), Gus Ali Jauhari (Pasuruan), dan masih banyak lagi. ${ }^{15}$

Kiai Abdul Hannan mempunyai karya, di antaranya kitab Sullam al-Futüh̆ät dan Siläḥ al-Muballighin. Kedua karya ini merupakan kompilasi dari beberapa kitab yang berisi tentang amalan-amalan yang dibutuhkan masyarakat. Kedua kitab ini mencoba mengompilasi ragam amalan yang didapat saat mempelajari kitab-kitab klasik selama menuntut ilmi. Varian amalan di dalamnya bersumber dari al-Qur'ān, Sunnah, dan hikmah para ḅukamä'. Kedua kitab tersebut ditulis dan

\footnotetext{
12 Ibid.

13 Ibid.

${ }^{14}$ K. H. Abdul Hannan, Wawancara, Pare 15 November 2015.

15 Misbahul Munir (Santri Senior Pesantren Fathul Ulum Kwagean Pare), Wawancara, Pare 25 Juni 2017.
} 
di-launching secara berkala setiap tahun. Sampai tahun 2017, kitab Sullam al-Futūhāt disusun sampai 20 volume, sedangkan kitab Silāh alMuballighin sampai volume keempat. Kedua kitab ini berkisar sampai 20 sampai 25 halaman sebesar buku saku tanggung. Ada kemungkinan kitab ini akan bertambah volumenya pada setiap tahun. Proses launching volume terbaru kitab karya Kiai Hannan biasanya dilaksanakan bersamaan dengan proses ijäzah kubrā di setiap tanggal 14 bulan Safar. ${ }^{16}$

Pada awalnya Sullam al-Futūhät merupakan lembaran-lembaran yang terserak. Amalan yang terdapat dalam kitab Sullam al-Futūhät merupakan amalan yang diberikan oleh Kiai Hannan kepada orangorang yang meminta ijazah amalan, baik mahabbah, penglarisan, dan lain-lain yang ditulis sendiri olehnya. Seiring berjalannya waktu, ragam lembaran ini kemudian dikompilasi hingga sampai volume dua puluh. Hal ini pula yang terjadi pada penyusunan kitab Siläḥ al-Muballighin.

Pembukuan pertama terjadi pada tahun $1996 \mathrm{M} / 1417$ H pada malam Jumat bulan Safar minggu kedua dan kiai sendiri yang menyusun urutan-urutan amalan tersebut. ${ }^{17}$ Menurut Kiai Abdul Qadir penulisan kitab Sullam al-Futūhät merupakan permintaan dari masyarakat-yang mengikuti pengajian rutinan pada malam Rabuyang menghendaki agar ragam amalan yang biasanya dilakukan Kiai Hannan dapat dikodifikasi dengan baik. Ragam amalan tersebut pada dasarnya sudah diberikan oleh kiai semenjak tahun 1982 saat jumlah santri masih sekira 50-an santri. ${ }^{18}$

Jika melihat dari kitab-kitab, seperti Sullam al-Futūhät dan Silāḥ alMuballigbin, yang diijazahkan kepada santri di tiap tahun, tidak mengherankan jika kiai Hannan juga biasa dijuluki dengan kiai tabib. ${ }^{19}$ Menariknya, jika dilihat secara saksama suluruh edisi kitab yang diijazahkan, didapati bahwa dalam merumuskan dan mengompilasi beberapa isi kitabnya, kiai tidak hanya merujuk pada satu kitab semata, tetapi beliau mampu mengombinasikan dengan banyak kitab. Bisa dikatakan bahwa selain disebut kiai tabib, beliau bisa dikategorikan kiai intelek karena wacana dan pemahamannya yang sangat luas pada

\footnotetext{
${ }^{16}$ Buku Alumni Pondok Pesantren Fathul Ulum Kwagean Pare, 2016.

17 Ibid.

${ }^{18}$ Ibid.

${ }^{19}$ Lihat M. Syamsul Huda, "Epistemologi Penyembuhan Kiai Tabib”, Islamica: Jurnal Studi Keislaman, Vol. 8, No. 1 (2013), 103-120.
} 
beragam kitab. Tidak ada satu pun rangkaian ijazah yang tidak pernah diamalkan olehnya.

\section{Konstruksi Sosial Teologis Ijazah Asma' Artho}

\section{A. Konstruksi Sosial Ijazah Asma' Artho}

Bagi masyarakat Muslim, terkadang mereka perlu mendapatkan sugesti tentang keberkahan uang yang selama ini dikelola untuk tujuan bisnis. Beberapa di antara para pemegang uang yang sudah di-asma-i menyatakan bahwa mereka percaya bahwa saat mereka memegang uang asma-an, rejekinya pun semakin lancar. Hal ini sebagaimana dituturkan oleh Hanafi yang menyatakan:

Sudah ketiga kalinya aku rutin melu acara ijazah Asma' Artho sejak tabun 2014. Perkembangan bisnisku alhamdulillah lancar. Awal melu acara ijazah-an aku cuma nga-asma-i 300 ewu, tahun kedua (2015) aku iso ngasma-i satu yuto, tabun ketiga aku ng-asma-i telung yuto. ${ }^{20}$

[Semenjak tahun 2014, saya sudah tiga kali ikut acara ritual ijazah Asma' Artho. Saya bersyukur bahwa bisnisku semakin lancar. Pertama kali ikut ijazah Asma' Artho, saya hanya meng-asma-i uang tiga ratus ribu rupiah. Di tahun 2015, saya bisa meng-asma-i uang sekira satu juta rupiah. Di tahun 2016, saya bisa meng-asma-i uang sekitar tiga juta rupiah].

Tidak semua peserta yang hadir adalah pengusaha atau wirausahawan, karena banyak dari kalangan santri yang tidak mempunyai latar belakang bisnis. Mereka hanya berharap keberkahan rejeki yang didapat. Sebagaimana yang dituturkan oleh salah satu santri Pondok Pesantren Fathul Ulum. Saat ditanya berapa ia mengasma-i uangnya. Ia menjawab mung limang ewu (hanya lima ribu). ${ }^{21}$

Para pengamal dan pemegang uang Asma sangat variatif. Ada dari kalangan wirausahawan, santri, dan para akademisi. Beberapa dari kalangan akademisi bahkan dari unsur dosen, selain aktivitas lain, seperti guru, mudin, dan lain sebagainya. Narasumber dari unsur dosen, misalnya, yang sempat ditemui oleh peneliti, adalah A. Mufti Khozin, dosen Fakultas Syariah dan Hukum Universitas Islam Negeri Sunan Ampel Surabaya dari Sumenep Madura. Khozin menyatakan bahwa ritual ini sudah sering dilakukannya. Bahkan dalam pengakuannya, ia mengetahui tradisi ijazah ini sudah cukup lama, karena ia sendiri alumnus pondok pesantren Fathul Ulum. Ia juga

\footnotetext{
${ }^{20}$ Hanafi (Wirausahawan di Gresik), Wawancara, Pare 26 Juni 2016.

21 Aziz Abidin (Santri Senior di Pondok Pesantren Fathul Ulum, Kwagean), Wawancara, 15 Juli 2016.
} 
pernah menjadi ketua panitia pada pelaksanaan ijazah Asma' Artho. Saat ditemui, Khozin menuturkan ia membawa beberapa orang yang juga meng-asma-i uangnya. Tidak hanya uang, barang-barang seperti sorban dan sabuk juga di-asma-i. Khozin menuturkan:

Beberapa masyarakat di daerah saya tertarik untuk mencari keberkahan harta bendanya. Mereka berharap sekali harta bendanya selalu berkah dan selalu terlimpah kepadanya rejeki yang halal. ${ }^{22}$

Penulis juga menemukan bahwa ada pelaku dan pengamal ijazah Asma' Artho dari kelompok mahasiswa program studi Ekonomi Syariah Universitas Islam Negeri Maulana Malik Ibrahim Malang. Saat ditemui oleh penulis, ia menegaskan bahwa karena latar belakangnya dari pesantren ia cukup familiar dengan tradisi ijazah ini. Saat ditanya oleh penulis, bahwa program studi yang ditempuhnya cukup rasional dalam mengelola keuangan, lantas kenapa masih mempercayai hal-hal irasional seperti ijazah Asma' Artho ini, ia menjawab: tradisi ini cukup familiar dengan latar belakang saya yang alumnus pondok pesantren. Saya percaya bahwa argumen-argumen teologis ijazah ini membawa keberkahan bagi pemegang barang asma, karena doa-doa yang dilantunkan. ${ }^{23}$

Keragaman peserta ijazah Asma' Artho ini memang sangat menarik di antaranya dari kelompok masyarakat awam dan santri. Adapun masyarakat awam melihat praktik ini dianggap lebih islami dan jauh dari praktik abnormal, seperti fenomena pesugihan lain yang terkadang ada ritual keluar dari mainstream agama. Hal ini, misalnya, ditemukan dalam riset Luzman Abdau yang melakukan riset pesugihan di Gunung Kemukus Sleman Yogyakarta. Dinyatakan bahwa para pelaku pesugihan di sana juga melakukan ritual hubungan seksual. Hasil penelitian ini menunjukkan bahwa para pelaku pesugihan mengetahui adanya hubungan seksual selama pelaksaan ritual. Mereka menganggap bahwa dengan melakukan hubungan seksual tersebut, keinginan mereka dapat dengan mudah dicapai. Hasil yang didapatkan setelah melakukan ritual pesugihan tersebut dapat berupa usaha atau pekerjaan yang semakin lancar, meskipun disisi lain ada juga yang belum mendapatkan hasil dari ritual pesugihan tersebut. $^{24}$

22 A. Mufti Khozin (Dosen Fakultas Syariah dan Hukum UIN Sunan Ampel), Wawancara, Pare 12 Mei 2017.

23 Ahmad Thayyib (Mahasiswa Program Studi Ekonomi Syariah UIN Maulana Malik Ibrahim Malang), Wawancara, Pare 27 Agustus 2016.

${ }^{24}$ Luzman Abdau, "Ritual Pesugihan di Gunung Kemungkus: Studi Deskriptif tentang Ritual di Gunung Kemungkus”, Jurnal Program Studi Sosiologi, 2013. 
Dalam tataran perilaku, maraknya fenomena perdukunan, pesugihan, jimat dan bekal-bekalan di kalangan masyarakat dan sebagainya merupakan suatu fenomena yang menjadi realitas dalam masyarakat Indonesia. Bahkan menurut Ruslani terdapat banyak tempat yang sangat dikeramatkan oleh masyarakat Jawa yaitu Gunung Kawi di Jawa Timur, gunung kemukus di Kedung Ombo, Jawa Tengah, dan gunung Guci di Slawi, Jawa Tengah. ${ }^{25}$

Kepercayaan atas kekuatan roh atau mitos tertentu merupakan bentuk lain pengaruh adat istiadat dan budaya terhadap sistem kepercayaan masyarakat Muslim. Wujud kepercayaan tersebut semisal upacara nyadran atau juga dikenal dengan sebutan petik laut. Upacara ini ditujukan untuk memberikan penghormatan dan sesembahan kepada penguasa laut yang dikenal dengan Nyi Roro Kidul. ${ }^{26}$ Wujud kepercayaan tersebut semisal upacara nyadran atau juga dikenal dengan sebutan petik laut. Upacara ini ditujukan untuk memberikan penghormatan dan sesembahan kepada penguasa laut yang dikenal dengan Nyi Roro Kidul.

Secara umum, dalam masyarakat Indonesia yang mayoritas beragama Islam, terdapat berbagai macam bentuk perilaku beragama masyarakat. Berbagai macam bentuk perilaku keagamaan tersebut dapat mengklasifikasi masyarakat menjadi tiga bagian, antara lain:

Pertama, masyarakat sinkretis. Untuk tipe pertama ini adalah masyarakat yang beragama Islam tetapi percaya kepada dukun, roh leluhur, paranormal, tukang sihir, arwah penasaran, dan lain-lain. Dalam perilaku keagamaan mereka masih memberikan sesajen untuk tempat-tempat yang dianggap keramat, masih mendatangi dukun untuk meminta pengobatan, masih mendatangi tempat-tempat angker untuk pesugihan, melakukan sihir, bekal-bekalan dan lain sebagainya.

Kedua, masyarakat puritan. Muslim kelompok berusaha menjalankan ajaran agama Islam secara tekstual dan jargon utamanya adalah kembali ke al-Qur'ān dan Sunnah. Kelompok ini cenderung bersikap tidak akomodatif terhadap kepercayaan masyarakat yang bersumber dari nilai budaya dan adat istiadat. Para pengkaji Islam di Indonesia menyebut mereka sebagai bagian dari gerakan puritan,

25 Ruslani, Tabir Mistik: Alam Ghaib dan Perdukunan dalam Terang Sains dan Agama (Yogyakarta: Tinta, 2003), 63.

26 Baiq Lily Handayani, "Transformasi Perilaku Keagamaan: Analisis terhadap Upaya Purifikasi Akidah Melalui Ruqyah Syariyah Pada Komunitas Muslim Jember", Jurnal Sosiologi Islam, Vol. 1, No. 2 (Oktober 2011), 73. 
sebagian lagi menyebutnya Islam reformis, Islam modern dan yang lain menyebutnya Islam revivalis.

Ketiga, masyarakat akomodatif. Kelompok ini adalah kelompok yang masih menerima ritual dan praktik yang masih ada argumentasi teologis. Sebagaimana praktik ijazah Asma' Artho yang dianggap mempunyai basis pemikiran teologis yang jelas. Misalnya rujukanrujukan otoritatif dari ritual ini diambilkan dari beberapa kitab yang dikarang oleh, misalnya, Abū Ḥāmid al-Ghazālī dan pengarang kitab I'ānat al-Ṭălibin karya Abū Bakr Muḥammad Shațā al-Dimyātūi

Fenomena ijazah Asma' Artho ini dianggap tidak "mengeksploitasi" biaya atau mahar dalam pengasmaan uang. Beberapa Lembaga yang menerima pengasmaan ijazah terkadang meminta mahar yang sangat mahal. Ini berbeda dengan biaya atau mahar yang harus dikeluarkan oleh masyarakat jika menginginkan uangnya di-asma-i agar berkah. Mahar uang yang diasmai adalah sebesar uang yang ingin di-asma-i. Jadi, jika ingin mengasmai uang lima ribu rupiah, maka yang uang yang disetorkan dengan maharnya adalah kelipatan uang tersebut, yakni sepuluh ribu rupiah.

Dalam konteks ini masyarakat cukup mudah mendapatkan uang asma tersebut, karena harga yang sangat terjangkau. Di samping itu, keterlibatan masyarakat untuk ikut berdoa bersama kiai dan para santri juga berdampak pada rasa ikut berkontribusi masyarakat terhadapa proses pengijazahan. Mereka terlibat dalam membaca Maulid Barjanzi sebelum uang dan barang yang akan di-asma-i dibacakan wirid oleh kiai dan para santri khusus.

Secara umum dapat digambarkan dari para peserta ijazah Asma' Artho bahwa mereka mencari keheningan dan ketenangan batin agar ada koreksi diri dan refleksi ke depan untuk bisnis yang dijalani, sekecil apapun bisnis tersebut. Karenanya, mereka menggunakan uang asma sebagai jimat atau azimat—sebagai wasilab—setidaknya untuk melancarkan rejekinya.

\section{B. Konstruksi Teologis Ijazah Asma' Artho}

Pada dasarnya praktik ritual ijazah Asma' Artho yang dilaksanakan di Pondok Pesantren Fathul Ulum Kwagean Pare Kediri mempunyai dasar-dasar teologis. Dalam amatan penulis saat proses ijazahan Asma' Artho, masyarakat yang mendaftarkan uangnya untuk di-asma-i diberikan selebaran yang berisi tentang dalil-dalil teologis agar terhindar dari ragam prasangka syirik. Biasanya, Kiai Hannan 
mengawali proses ijazah tersebut dengan menjelaskan kronologi pengijazahan ini yang awalanya adalah permintaan dari masyarakat dan santri. Sampai akhirnya ritual ini menjadi sebuah tradisi setiap tanggal 12 Rabiul Awwal setiap tahun. ${ }^{27}$

Beberapa argumentasi teologis mendasari ritual peng-ijazah-an Asma' Artho, di antaranya:

Pertama, Ma'rūf al-Karkḥ̄ mengatakan: barangsiapa membaca maulid Nabi saw. pada beberapa dirham berlapis perak atau emas, kemudian dirham-dirham tersebut digabungkan dengan dirham yang lain, maka dirham-dirham tersebut akan mendapatkan berkah. Pemiliknya tidak akan mendapatkan kefakiran dan kekurangan harta, karena keberkahan maulid Nabi saw. ${ }^{28}$

Kedua, sebagaimana dirujuk dari kitab al-Awfāq karya Abū Ḥāmid al-Ghazālī disebutkan: "Barangsiapa menuliskan al-Bāsit_-salah satu nama Allah—dan digantungkan dalam rumah, maka ia akan didatangi rejeki setiap harinya. ${ }^{29}$

Ketiga, beberapa ulama khäs klasik pernah menyatakan bahwa: "Untuk mendapatkan keberkahan dan kelancaran (rejeki), maka hendaknya dibacakan ayat kursi untuk makanan yang sedikit atau gandum, anggur kering, beras atau lainnya. Setiap kali anda membaca untuk makanan-makanan tersebut, maka makanan tersebut akan mengembung (menjadi berlipat ganda) sampai sejumlah para rasul. Sesungguhnya keberkahan dan kelancaran itu terjadi karena kehendak Allah. Hal itu pula akan terjadi jika dibacakan pada dirham-dirham. Ini adalah salah satu keistemewaan al-Qur'ān. ${ }^{30}$

Dalam kitab Shumüsh al-Anwär disebutkan bahwa dalam menarik keberkahan pada buah-buahan seperti anggur dan kurma adalah dengan menuliskan sebuah rajah (al-khätam) di sebuah kertas pada hari senin dengan naqsh lalu bubuhilah wewangian dan letakkan di tengahtengah tangan anda buah-buahan tersebut. Angkatlah (makanlah) dalam keseharian, namun ketika memakannya hendaknya ia membaca

\footnotetext{
27 Observasi di Pondok Pesantren Fathul Ulum di Kwagean Pare 24 Agustus 2016.

28 Abū Bakr 'Uthmān b. Muhammad Shaṭā al-Dimyāṭī al-Shāfi'ī, I'ánat al-Ṭalibìn, Vol. 3 (Surabaya: Maktabah al-Hidayah, t.th.), 364.

${ }^{29}$ al-Ghazālī, al-Awfäq, 32.

30 Muḥammad Ḥaqqī al-Nāzilī, Khaẓnat al-Asrār Jalīlat al-Adhkēar (Mesir: Muṣtafā alBāb al-Halabī, t.th.), 128.
} 
al-azimah, maka makanan tersebut tidak akan berkurang. Perbaruilah amalan ini setiap awal tahunnya. ${ }^{31}$

Sebagaimana dikutip dalam kitab al-Ni'mah al-Kubrā 'alā al-'Ālam fì Mawlid Sayyid Walad Adam karya Ibn Hajar al-Haythamī yang dinyatakan bahwa "barangsiapa membaca maulid Nabi saw. pada dirham-dirham maka akan ditemukan barakah di dalamnya dan pemiliknya tidak akan fakir dan tangannya tidak akan kekurangan harta sebab keberkahan maulid Nabi saw". 32

Terkait dengan penulisan Asma Allah, al-Bäsit, sebagaimana yang tertuang pada poin kedua di atas, 'Abd al-Maqșūd Muhammad Sālim dalam buku Fì Malakèt Allah ma'a Asmā Allah menyatakan setiap Asmä' Allah memiliki jumlah khusus dan setiap jumlah memiliki martabat-martabat di mana sebaiknya pezikir tidak melampaui batasannya. Prinsipnya, menzikirkan Asmä' Allah itu harus berdasarkan jumlahnya yang sesuai dengan tiap-tiap $A s m \bar{a}^{\prime}-\mathrm{Nya}$. Ada yang mengatakan prinsip tersebut merupakan pintu wusül dan malampaui jumlahnya bisa membahayakan terutama bagi yang tidak memiliki murshid. Sebab sudah menjadi kemestian bahwa engkau harus dibimbing oleh seorang murshid dan seorang 'árif yang mengajarkanmu tingkatan-tingkatan rohani (ma'älim al-tanæil). ${ }^{33}$

Allah berfirman dalam Q.S. al-Ra'd [13]: 26 yang artinya "Allah melapangkan rejeki bagi siapa yang Dia kehendaki dan membatasi (bagi siapa yang Dia kehendaki). ${ }^{34}$ Makna al-Bassit adalah bahwa Allah adalah Dzat yang melapangkan rejeki kepada siapa saja yang Dia kehendaki untuk hamba-Nya. Ada pendapat yang mengatakan bahwa Asmä' ini adalah zikir Malaikat Israfil. ${ }^{35}$ Kehendak Allah sangat independen dalam melapangkan atau menyempitkan rejeki. Dia bisa menguatkan rejeki bagi orang tidak beriman, dan melemahkan rejeki

\footnotetext{
31 Ibn al-Ḥàj al-Tilimsānī al-Maghribī, Shumūs al-Anwār wa Kunūz al-Asrār al-Kubrā (t.t.: t.tp., t.th.), 51 .

32 Ibn Hajar al-Haythamī, al-Ni'mah al-Kubrā 'alā al-'Ālam bi Mawlid Sayyid Walad $\bar{A} d a m$ (t.t.: t.tp., t.th.), 9.

33 'Abd al-Maqșūd Muḥammad Sālim, Fì Malakūt Allah ma'a Asmā Allah (Kairo: Shirkat al-Sharlā li al-Ṭab“ wa al-Nashr wa al-Adawāt al-Kitābīyah, 2003), 22.

34 Muhammad 'Alī al-Ṣābūnī, Șafwat al-Tafäsìr: Tafsìr li al-Qur'àn al-Karìm, Vol. 2 (Libanon: Dār al-Fikr, 2001), 76.

${ }^{35}$ Sālim, Fì Malakūt Allah, 22.
} 
bagi yang beriman. ${ }^{36}$ Kemurahan dan rahmat Allah adalah kunci segalanya. ${ }^{37}$ Akan tetapi seseorang yang mendapatkan keluasan rejeki bukan berarti seseorang mendapatkan kemuliaan, dan tidak mendapatkan rejeki bukan berarti ia dihina. Kekayaan dan kemiskinan manusia bukan tolok ukur Allah suka dan tidak suka. ${ }^{38}$

Siapa saja yang berzikir al-Bäsit dan dia memiliki hajat tulus dan mendesak, maka Allah akan lapangkan rejeki baginya. Allah hidupkan kalbunya. Allah hilangkan gundah-gelisahnya. Allah jadikan setiap tahun yang melihatnya mencintainya. ${ }^{39}$

Kebanyakan dari kita menginginkan pengabulan yang cepat seraya berkata: "Ya Tuhanku, kenapa tidak segera mengabulkanku?" Lalu ia berprasangka buruk kepada Tuhannya. Maka ini bukan termasuk adab dan kebiasaan seorang Muslim. ${ }^{40}$

Seorang hamba saleh berkata, "Aku pernah memohon kepada Allah sebuah hajat selama kurang lebih empat puluh tahun, dan Dia memberiku. Namun aku tidak lantas mewujudkannya dengan cara yang buruk". Inilah contoh penyerahan diri dan kepasrahan kepada Allah terhadap segala perkara yang kita hadapi pra dan pasca-perkara itu terealisasi. Pahami isyarat dari ayat ini, “...dan katakanlah, "Mudah-mudahan Tuhanku akan memberiku petunjuk kepadaku agar aku yang lebih dekat (kebenarannya) daripada ini". (Q.S. al-Kahf [18]: $24 .^{41}$

Dalam konteks penyebutan dan zikir al-Bäsit, sebagian ahli makrifat, seperti Abū Ḥāmid al-Ghazālī, Muḥammad Mạ̣mūd alNajd̄̄ ${ }^{42}$ dan menjelaskan bahwa penyebutan Asma Allah al-Bäsit biasa diawali dengan Asma Allah yang lain, al-Qäbid yang artinya Maha

\footnotetext{
${ }^{36}$ Muhammad b. Aḥmad al-Khaṭỉb al-Sharbīnī al-Miṣrī, al-Sirāj al-Munir fì al-T'ānah 'alā Ma'rifat ba'd Ma'ānì Rabbunā al-Hakìm al-Khabìr (Kairo: Maṭba'at Būlāq, t.th.), 177.

37 'Abd al-Razzāq al-Kāshānī, Mu'jam Iștilāhạt al-Ṣ̂̄ìyah, 'Abd al-'Āl Shāhīn (ed.) (Kairo: Dār al-Mannār, 1992), 354.

38 Beberapa orang kafir bergembira dengan status kekayaaannya. Hal itu karena mereka tidak mengetahui kadar dunia dan status di hari akhir nanti. Abī Bakr Jābir al-Jazāirī, Aysar al-Tafāsìr li Kalām al-'Alìyy al-Kabìr, Vol. 3 (Kairo: Dār al-Salām li alȚibā'ah wa al-Nashr wa al-Tawzī' wa al-Tarjamah, 1994), 26.

${ }^{39}$ Ibid., 62.

40 Dikutip dari Muhy al-Dīn b. 'Arabī, Kashf al-Ma'nā 'an Sirr Asmà Allah al-Husnā (Beirut: Muassasat al-'Urwah al-Wuthqā, 2008), 93.

${ }^{41}$ Ibid.

${ }^{42}$ Lihat Abū Hāāmid al-Ghazālī, al-Maqsad al-Asnā fì Sharḥ Asmā Allah al-Husnā, Muḥammad 'Uthmān Khisht (ed.) (Kairo: Maktabat al-Qur’ān, 2001), 142.
} 
Menahan. Hal ini sebagaimana yang tertuang dalam Q.S. al-Baqarah [2]: 245 yang berbunyi wa Allah yaqbidu wa yabsutu wa ilayh turja'ün [Allah menahan dan melapangkan rejeki. Kepada-Nya semua dikembalikan]. ${ }^{43}$ Alasannya, Allah tidak disifati Maha Menahan (alQäbid) rejeki saja tanpa disifati Maha Memberi (al-Bäsit) rejeki. Pula sebaliknya, Allah tidak akan disifati Maha Memberi kecuali disifati Maha Menahan rejeki. ${ }^{44}$ Kedua sifat dianggap sebagai sebuah kebijaksanaa saat Allah disifati dengan Maha Menahan (al-Qäbid), maka Dia harus melestarikan juga dalam memberi rejeki umat manusia. $^{45}$

Ada pula pendapat yang mengatakan bahwa makna al-Qäbid adalah Allah menggenggam (qäbid) ruh-ruh manusia menjelang kematiannya dan melepaskan kembali ke dalam jasad ketika dibangkitkan dari kubur. ${ }^{46}$ Asma Allah ini termasuk zikir yang selalu dibaca oleh malaikat Izrail. Siapa saja yang dizalimi lalu menjadikannya zikir harian, maka Allah hancurkan orang yang menzaliminya itu. Akan tetapi menurut Sālim, dia tidak akan menjelaskan poin ini kecuali dengan pengetahuan yang mendalam. Sebab, bukanlah syiar Muslim untuk membalas dendam. Memaafkan termasuk kebiasaan yang mulia. ${ }^{47}$

\section{Membaca Rumus Wifiq pada Asma'Artho}

Wifiq, wafaq, atau wafq secara etimologis berasal dari kata wafiqyafiq-wafqan berarti ja'alah muwäfiqan aw mulaiman yang artinya menjadikan sesuatu itu selaras, cocok, sesuai, atau harmonis atau kān sawäban muwäfiqan li al-muräd yang berarti dia benar dan menyetujui sesuai

\footnotetext{
${ }^{43}$ Untuk memahami ayat ini, bisa juga dikorelasikan dengan Q.S. Saba' [34]: 39 yang artinya: "Katakanlah: Sesungguhnya Tuhanku melapangkan rejeki bagi siapa yang dikehendaki-Nya di antara hamba-hamba-Nya dan menyempitkan bagi (siapa yang dikehendaki-Nya)" atau Q.S. al-Rūm [30]: 37 yang artinya "Dan apakah mereka tidak memperhatikan bahwa Sesungguhnya Allah melapangkan rejeki bagi siapa yang dikehendaki-Nya dan Dia (pula) yang menyempitkan (rejeki itu). Sesungguhnya pada yang demikian itu benar-benar terdapat tanda-tanda (kekuasaan Allah) bagi kaum yang beriman'. Lihat 'Abd al-Hamīd Kishk, Asmā Allah al-Husnā: Ma'nāhā, Faḍlubā, al-Du'à bihā (Kairo: al-Mukhtār al-Islāmī li al-Ṭab' wa al-Nashr wa alTawzī', t.th.), 115.

${ }^{44}$ Muḥammad Maḥmūd al-Najdī, al-Nahj al-Asmā fì Sharḥ Asmà Allah al-Husnā, Vol. 1 (Kuwait: Maktabah al-Imām al-Dhahabī, t.th.), 124.

${ }^{45}$ Kishk, Asmā Allah al-Husnā, 115.

${ }^{46}$ Sālim, Fì Malakùt Allah, 61.

47 Ibid.
} 
yang dimaksud. Al-Layth mengatakan wafq berarti segala sesuatu yang disepakati pada satu kesepakatan sebagaimana ungkapan wäfaqtu fulānan fi mawdi kadhā (saya setuju dengannya). ${ }^{48}$ Sedangkan secara umum pengertiannya berarti suatu tulisan yang terdiri dari ragam angka, huruf, atau kata yang disusun secara sistematis mengikuti kaidah yang sudah ditentukan untuk membentuk pola enargi yang diinginkan. Wafaq atau wifiq tersebut dapat digunakan sebagai sarana penyembuhan, perlindungan, keselamatan, kemudahan rejeki, dan lain-lain sesuai keingingan pembuat wafaq. ${ }^{49}$

Dalam konteks penelitian ini wifiq yang dibahas kali ini adalah tulisan atau simbol yang terdapat pada uang yang telah diasmai dan dicantumkan simbol. Sejumlah huruf didistribusikan dalam enam belas kolom yang jika diperhatikan ada empat huruf yang diulang sebanyak empat kali. Huruf-huruf tersebut antara lain $b \bar{a}$, alif, sin, dan tă. Jika diakumulasi, huruf-huruf tersebut bisa dibaca bāsit. Berikut gambar yang terdapat dalam uang yang di-asma-i.

\begin{tabular}{|c|c|c|c|}
\hline ط & س & 1 & ب \\
\hline ب & 1 & س & b \\
\hline س & b & ب & 1 \\
\hline 1 & ب & b & س \\
\hline
\end{tabular}

Tabel 1.1. Wifiq dalam Asma' Artho

Penulisan wifiq pada Asma' Artho diambilkan dalam salah satu nama Allah pada Asmā' al-Husnāa, yakni al-Bāsit yang berarti Yang Maha Sederhana. Keempat huruf dalam al-Bāsit_yakni bä', alif, sin, dan $t \bar{a}$ - - kemudian ditulis secara terpisah. Pada dasarnya, dalam ilmu peletakan wifiq, seseorang dapat leluasa mempola kolom pada wifiq, bisa dibuat tiga (muthallath), empat (murabba), lima (mukahmmas), enam (musaddas), dan seterusnya. Yang terpenting seseorang dapat meletakkan pecahan huruf agar terbaca sesuai dengan rumus wifiq. Artinya, pecahan huruf yang terbaca tadi bisa diakumulasi melalui

\footnotetext{
${ }^{48}$ Majma' al-Lughah al-'Arabìyah, al-Mu'jam al-Wasit (Kairo: Maktabah a-Shurūq alDawlīyah, Cet. Ke-4, 2005), 1046.

${ }^{49}$ Ibid.
} 
segala arah dari kolom yang dibuat dan dapat dijumlah dengan nilai yang sama.

Supaya mengetahui jumlah $A s m \vec{a}$ yang telah disebutkan, maka engkau harus mengetahui jumlah bagi setiap huruf yang ada. Keterangannya sebagai berikut:

\begin{tabular}{|c|c|c|c|c|c|c|c|c|c|}
\hline ي & b & $\tau$ & j & و & 。 & دد & ج & ب & 1 \\
\hline 10 & 9 & 8 & 7 & 6 & 5 & 4 & 3 & 2 & 1 \\
\hline & ق & ص ص & ف & $\begin{array}{l}\varepsilon \\
70\end{array}$ & س & $\begin{array}{l}\dot{U} \\
50\end{array}$ & $\vec{r}$ & J & $\begin{array}{c}5 \\
50\end{array}$ \\
\hline & & $\begin{array}{c}\dot{\varepsilon} \\
1000\end{array}$ & $\begin{array}{c}\text { ظ } \\
900\end{array}$ & ض & $\begin{array}{c} \\
700\end{array}$ & $\begin{array}{c}\dot{\tau} \\
600\end{array}$ & \begin{tabular}{c}
\multirow{3}{*}{} \\
500
\end{tabular} & $\begin{array}{c} \\
400\end{array}$ & ش \\
\hline
\end{tabular}

Tabel 1.2: Kaidah ilmu huruf di kalangan ahli hisab dan wifiq ${ }^{50}$

Jika huruf dalam Asma' Artho diakumulasi, maka huruf $b \vec{a}$, alif, sin, dan têa' dalam Asma' Artho dapat dinilai sebagai berikut: huruf $b \vec{a}$, bernilai dua, alif bernilai satu, $\sin$ bernilai enam puluh, dan $t \bar{a}$ ' bernilai sembilan. Lihat pada gambar di bawah ini.

\begin{tabular}{|l|c|c|c|c|}
\hline Huruf & $b$ & $\omega$ & 1 & + \\
\hline Jumlah & 9 & 60 & 1 & 2 \\
\hline Total & \multicolumn{5}{|c|}{72} \\
\hline
\end{tabular}

Tabel 1.3 Jumlah bilangan Asma Allah, al-Bäsit

Jika diperhatikan secara saksama, jumlah nilai wifiq dalam pola empat kolom adalah tujuh puluh dua. Jumlah itu juga akan sama nilainya jika dihitung dari arah yang berbeda. Perhatikan gambar kolom berikut ini.

1. Hitungan vertikal. Jika dijumlahkan, tetap bernilai tujuh puluh dua.

A

\begin{tabular}{|c|c|c|c|}
\hline 9 & 60 & 1 & 2 \\
\hline 2 & 1 & 60 & 9 \\
\hline 60 & 9 & 2 & 1 \\
\hline 1 & 2 & 9 & 60 \\
\hline
\end{tabular}

C

\begin{tabular}{|l|l|l|l|}
\hline & & & \\
\hline & & & \\
\hline 60 & 9 & 2 & 1 \\
\hline & & & \\
\hline
\end{tabular}

B

\begin{tabular}{|l|l|l|l|}
\hline 9 & 60 & 1 & 2 \\
\hline & & & \\
\hline & & & \\
\hline & & & \\
\hline
\end{tabular}

D

\begin{tabular}{|l|l|l|l|}
\hline & & & \\
\hline & & & \\
\hline & & & \\
\hline 1 & 2 & 9 & 60 \\
\hline
\end{tabular}

2. Hitungan horizontal. Jika dijumlahkan tetap bernilai tujuh puluh dua.

${ }^{50}$ Sālim, Fì Malakūt Allah, 25. 
A

\begin{tabular}{|c|l|l|l|}
\hline 9 & & & \\
\hline 2 & & & \\
\hline 60 & & & \\
\hline 1 & & & \\
\hline
\end{tabular}

C

\begin{tabular}{|l|l|c|l|}
\hline & & 1 & \\
\hline & & 60 & \\
\hline & & 2 & \\
\hline & & 9 & \\
\hline
\end{tabular}

$\mathrm{B}$

\begin{tabular}{|l|c|l|l|}
\hline & 60 & & \\
\hline & 1 & & \\
\hline & 9 & & \\
\hline & 2 & & \\
\hline
\end{tabular}

$\mathrm{D}$

\begin{tabular}{|c|c|c|c|}
\hline & & & 2 \\
\hline & & & 9 \\
\hline & & & 1 \\
\hline & & & 60 \\
\hline
\end{tabular}

3. Hitungan diagonal. Jika dijumlahkan tetap bernilai tujuh puluh dua.

A

\begin{tabular}{|l|l|l|l|}
\hline 9 & & & \\
\hline & 1 & & \\
\hline & & 2 & \\
\hline & & & 60 \\
\hline
\end{tabular}

$\mathrm{B}$

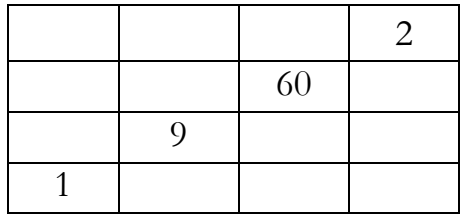

4. Hitungan secara acak, Jika dijumlahkan, tetap bernilai tujuh puluh dua.

A

\begin{tabular}{|l|l|c|c|}
\hline & & 1 & 2 \\
\hline & & 60 & 9 \\
\hline & & & \\
\hline & & & \\
\hline
\end{tabular}

C

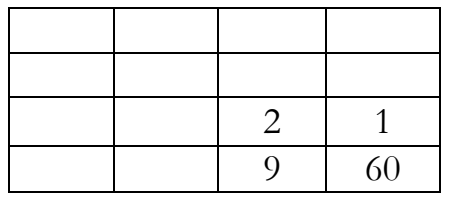

$\mathrm{B}$

\begin{tabular}{|c|c|c|c|}
\hline 9 & 60 & & \\
\hline 2 & 1 & & \\
\hline & & & \\
\hline & & & \\
\hline
\end{tabular}

$\mathrm{D}$

\begin{tabular}{|c|c|c|c|}
\hline & & & \\
\hline & & & \\
\hline 60 & 9 & & \\
\hline 1 & 2 & & \\
\hline
\end{tabular}

$\mathrm{E}$

\begin{tabular}{|c|c|c|c|}
\hline & & & \\
\hline & 1 & 60 & \\
\hline & 9 & 2 & \\
\hline & & & \\
\hline
\end{tabular}

Dilihat dari penempatan angka, wifiq genap mempunyai dua bentuk. Pertama, Sirr al-Tadakbkhul (seperti pola huruf "L"). Bentuk ini biasa disebut Aqilan diambil dari kaidah azilan satwad ya'ajjub bubbumak. Ada tiga model membuat wifiq ini, antara lain: a). Azilan 
Matrad; b). Aqilan Ghazäli; c). Azilan Nisf al-Dalí. Kedua, Basițah (penempatan huruf merata di seluruh arah). ${ }^{51}$

Adapun wifiq ini menggunakan rumus wifiq Azilan Ghazäli. Langkah pertama membuat wifiq Azilan Ghazäli adalah dengan membuat 16 kolom yang dibagi empat kolom. Kemudian kaidah Azilan dimasukkan dengan urutan sebagai berikut.

1 Lafal Arilan dimasukkan pada empat kotak awal dari kanan

\begin{tabular}{|l|l|l|l|}
\hline & & $i$ & $ن$ \\
\hline & & $j$ & $j$ \\
\hline & & & \\
\hline & & & \\
\hline
\end{tabular}

3 Lafal Ya'ajjuh dimasukkan pada 4 empat kotak ketiga

\begin{tabular}{|l|l|l|l|}
\hline & & & \\
\hline & & & \\
\hline & & $\varepsilon$ & $ج$ \\
\hline & & \& & ( \\
\hline
\end{tabular}

2 Lafal Satwad dimasukkan pada Empat kotak kedua

\begin{tabular}{|l|l|l|l|}
\hline & & & \\
\hline & & & \\
\hline$g$ & $b$ & & \\
\hline$د$ & w & & \\
\hline
\end{tabular}

$4 \quad$ Lafal Hubb ma dimasukkan pada empat kotak keempat dimasukkan

\begin{tabular}{|l|l|l|l|}
\hline S & $\tau$ & & \\
\hline$r$ & + & & \\
\hline & & & \\
\hline & & & \\
\hline
\end{tabular}

Jika digabungkan dan huruf-huruf tersebut dikonversi ke angka sesuai kaidah abjadun di atas adalah sebagai berikut:

\begin{tabular}{|c|c|c|c|}
\hline ك5 & $\tau$ & i & ن ن \\
\hline r & ب & j & ل \\
\hline g & b & $\varepsilon$ & ج \\
\hline د & س & ي & هـ \\
\hline
\end{tabular}

Konversi ke Angka

\begin{tabular}{|c|c|c|c|}
\hline 11 & 8 & 1 & 14 \\
\hline 13 & 2 & 7 & 12 \\
\hline 6 & 9 & 16 & 3 \\
\hline 4 & 15 & 10 & 5 \\
\hline
\end{tabular}

Yang perlu diperhatikan dalam pembuatan wifiq adalah peletakan kunci huruf (miftăh al-hurüf) dulu. Miftăh huruf biasanya adalah huruf terkecil dari lafal yang dibuat wifiq. Jika lafal bäsit dengan melihat hitungan abajadun adalah alif yang bernilai satu. ${ }^{52}$ Dalam wifiq bāsit ini yang menggunakan empat kotak. Langkah pertama adalah memecah lafal bāsit pada permukaan kotak pertama sebagaimana berikut:

\footnotetext{
${ }^{51}$ Ishạāq al-Ḥāfiḍ al-Sālājārī, Durrat al-'A'dād fì Tlm Wad'i al-Awfāq (Kediri: PP Fathul Ulum, t.th.), 43.

52 Ibid., 21.
} 


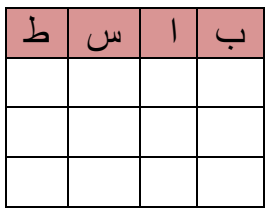

Berdasarkan angka-angka yang sudah terletakkan sesuai rumus Azilan Ghazāì di atas, cukup tergambar bagaimana memasukkan angka dalam wifiq Azilan Ghazăli memakai bentuk huruf "L" sempurna sebagai berikut: ${ }^{53}$

1. Hanya melihat angka 1 sampai dengan 4:

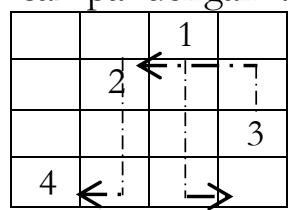

Alif diletakkan sebagai kunci huruf pada tempatnya angka 1-4:

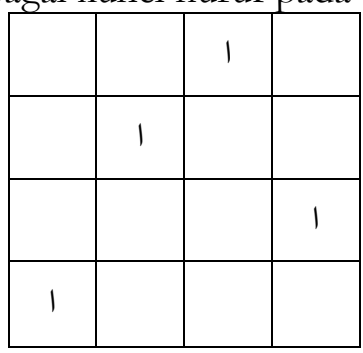

2. Hanya melihat angka 5 sampai dengan 8:

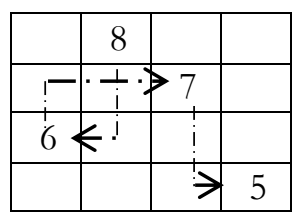

Meletakkan sin yang jatuh setelah alif dalam lafal bāsit pada tempatnya angka 5-8:

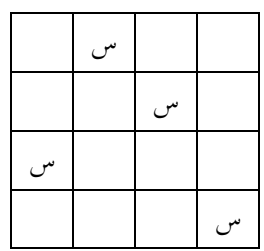

3. Kemudian hanya melihat angka 9 sampai dengan 12 :

${ }^{53}$ Ibid., 44-45. 


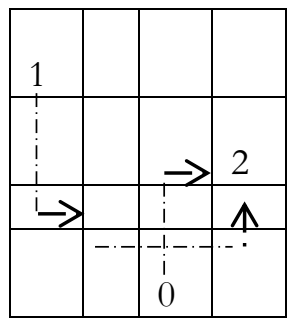

Meletakkan ță' pasca-lafal sin dalam lafal bāsit pada tempatnya angka 9-12:

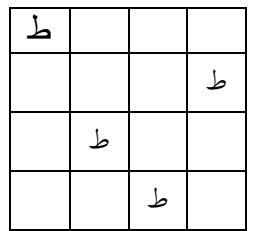

4. Lalu hanya melihat angka 13 sampai dengan 16 :

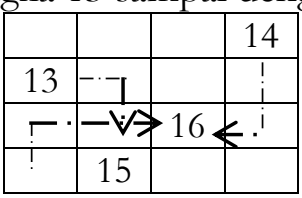

Meletakkan $b \bar{a}$ ' yang menjadi huruf terakhir pada lafal bāsit yang belum mendapat tempat pada tempatnya angka 13-16:

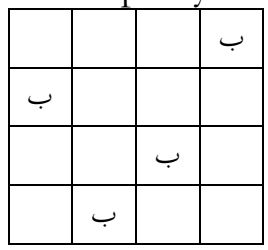

Dari empat langkah peletakkan huruf dalam wifiq tersebut jika digabung, maka akan terbentuk seperti wifiq asma arta di atas, yaitu:

\begin{tabular}{|l|l|l|l|}
\hline$b$ & $w$ & 1 & + \\
\hline$ب$ & 1 & $w$ & $b$ \\
\hline & $b$ & $ب$ & 1 \\
\hline 1 & $ب$ & $b$ & $\omega$ \\
\hline
\end{tabular}

Wifiq ini dapat terbaca sebagai mana berikut:

\begin{tabular}{|l|l|l|l|}
\hline & & 1 & + \\
\hline & & $w$ & $b$ \\
\hline & & & \\
\hline & & & \\
\hline
\end{tabular}

\begin{tabular}{|l|l|l|l|}
\hline & & & \\
\hline & & & \\
\hline & & + & 1 \\
\hline & & $b$ & $w$ \\
\hline
\end{tabular}




\begin{tabular}{|c|c|c|c|}
\hline$b$ & $w$ & & \\
\hline+ & 1 & & \\
\hline & & & \\
\hline & & & \\
\hline
\end{tabular}

\begin{tabular}{|l|l|l|l|}
\hline & & & \\
\hline & & & \\
\hline$س$ & $b$ & & \\
\hline 1 & $e$ & & \\
\hline
\end{tabular}

Apa yang terurai di sini hanya sekilas untuk memudahkan cara membaca wifiq. Pascafase pengetahuan tentang kaidah-kaidah dasar penulisan wifiq, langkah selanjutnya adalah kemampuan menjalin energi gaib. Agar azimat tersebut dapat berdayaguna, maka harus ada beberapa fase pembacaan wirid dan doa agar energi tersebut masuk dalam uang yang diasmai.

\section{Wirid Ritual Ijazah Asma' Artho}

Ritual pembacaan wirid Asma' Artho dilaksanakan pada tiga fase. Fase pertama wirid dibaca bersama kiai, para santri, dan para tamu yang akan mengijazahkan uangnya untuk di-asma-i. Fase kedua, setelah pembacaan wirid pada fase awal, semua uang dan benda yang ingin diasmai dibawa ke ndalem Kiai Hannan untuk dibaca oleh kiai beserta santri-santri khusus dan terpilih. Fase ketiga, kiai secara pribadi akan membaca wirid terhadap semua uang dan benda-benda. ${ }^{54}$

Adapun wirid-wirid yang dibaca pada fase awal adalah membaca Maulid Barjanzi secara bersama-sama antara Kiai Hannan, santri, dan para tamu yang mengijazahkan uangnya.

Sedangkan wirid fase kedua yang dibaca, antara lain:

1. Shalawat 1000 kali.

2. Yā Bāsit 1000 kali.

3. Yā Badī' 946 kali.

4. Q.S al-Wāqi'ah [56] 125 kali.

5. Q.S. al-Baqarah [2]: 2594444 kali.

6. Q.S. al-Haji [22]: 27. Saat sampai pada ayat kedua puluh delapan yang berbunyi li yashbadū manäfi lahum, ayat tersebut dibaca 4444 kali. $^{55}$

7. Q.S. al-Fātiḥah [1] tujuh kali.

8. Q.S. al-Nās [114] tujuh kali.

54 Tim Penulis, Kumpulan Mujahadah Panitia Ijazah Kubro dan Asma' Artho 1434 H (t.t.: Pesantren Fathul Ulum Kwagean Krenceng Kepung Kediri, 2016), 20-26.

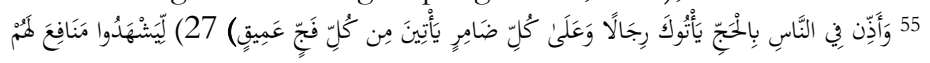


9. Q.S. al-Falaq [113] tujuh kali.

10. Q.S. al-Ikhlās [112] tujuh kali.

11. Q.S. al-Kāfirūn [109] tujuh kali.

12. Ayat kursi tujuh kali.

13. Tasbih sebanyak tujuh kali.

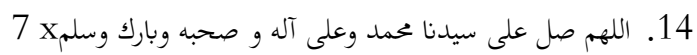

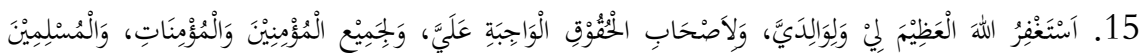

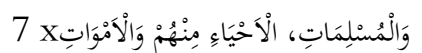

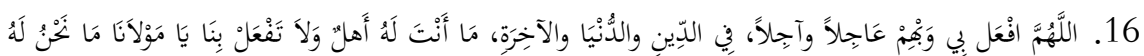

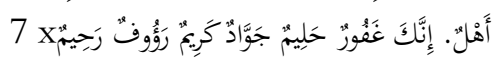

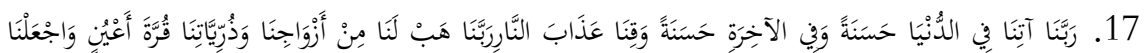

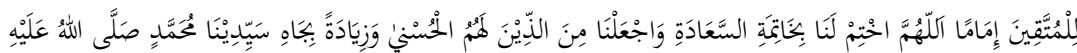

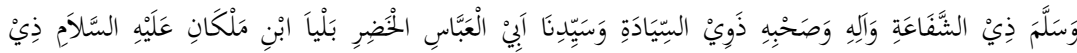

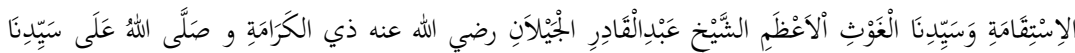

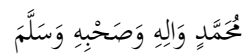

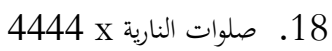

19. Q.S. al-Fātiḥah [1] $4444 \mathrm{x}$

20. Q.S. al-Baqarah [2]: $2554444 \mathrm{x}$

21. دُعَاء أيَّة الكُرْبِيسي

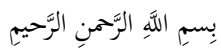

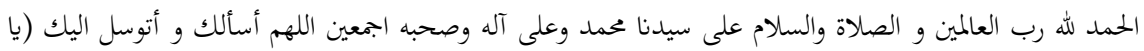

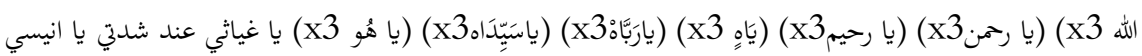

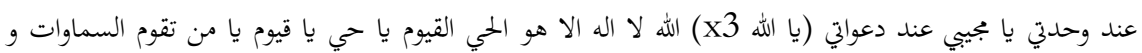

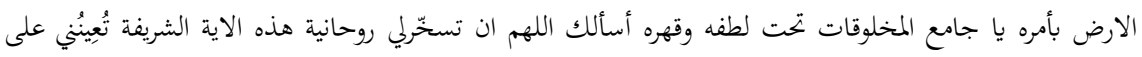

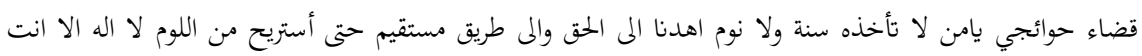

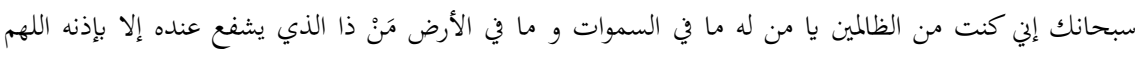

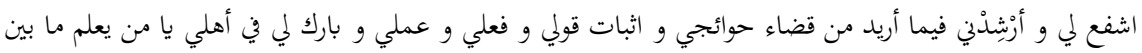

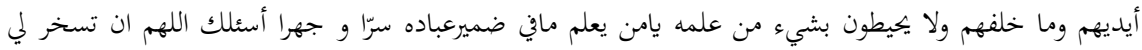

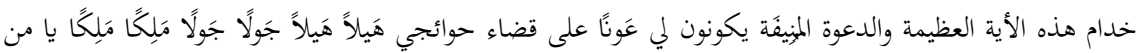

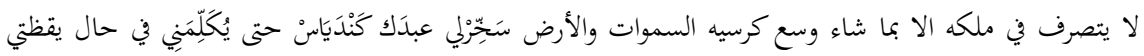

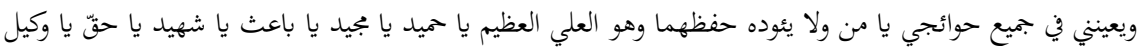

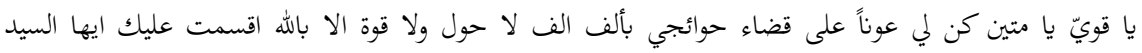

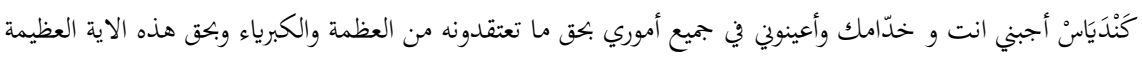


وبسيدنا محمد عليه الصلاة و السلام أجِبْ ايها السيد كَنْدَيَّْ أسرع من البرق وما أمر الساعة الا كَلَمْحَ البصر او

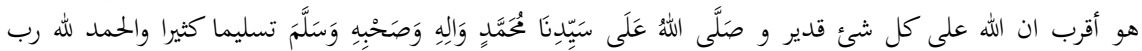

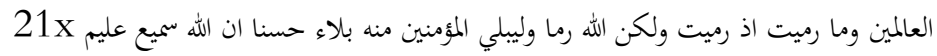
22. Q.S. al-Ikhlāṣ [112] 4444x

$$
\text { 23. بِسمِ اللَّهِ الرَّمنِ الرَّحيمِ }
$$

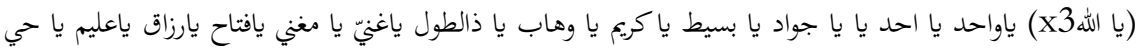

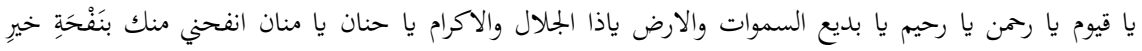

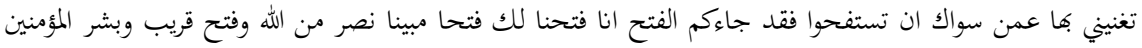

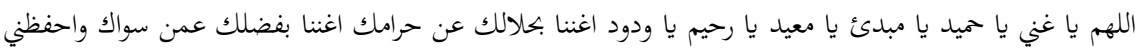

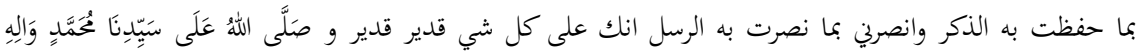

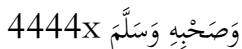
4444x 24 حَسْبُنَا اللَّهُ وَنِعْمَ الْوَكِيل

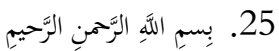

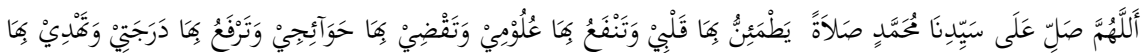

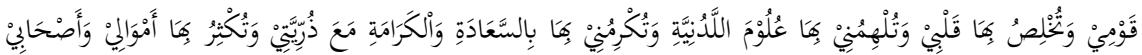

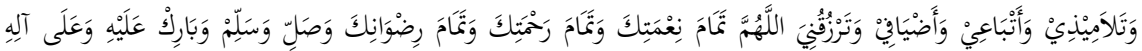

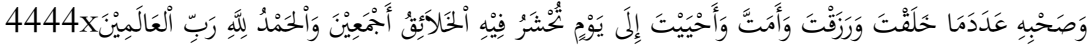

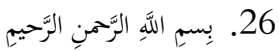

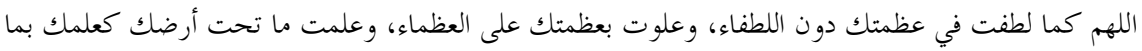

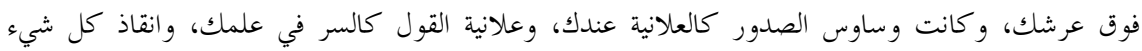

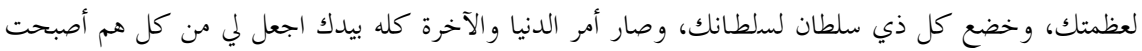
أو أمسيت فيه فرجا ومخرجا. اللهم إن عفوك عن ذنوبي وتجاوزكك عن خطيئاتي وسترك على قبيح عملي أطمعني

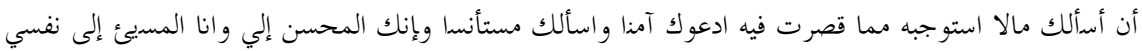
فيما بيين وبينك، تتودد إلي بنعمتك واتبغض إليك بالمعاصي ولكن الثقة بك حملتني على الجرأة عليك فجد

$$
\text { 4444x بفضلك وإحسانك علي إنك أنت التواب الرحيم }
$$$$
\text { 27. ان هذا لرزقنا ماله من نفاد 4444x }
$$

Untuk pembacaan wirid fase ketiga yang dibaca oleh Kiai Hannan, sejauh ini belum bisa dibuka secara umum, karena hal itu menjadi hal yang sangat privat. Bahkan para santri senior dan santri yang ikut membaca wirid pada fase kedua juga tidak mengetahui apa yang dibaca kiai pada fase akhir pembacaan wirid untuk meng-asma-i uang tersebut. Setelah proses pembacaan wirid fase ketiga selesai dilakukan, keesokan harinya uang yang di-asma-i bisa diambil oleh para tamu. 


\section{Penutup}

Masyarakat yang mengikuti ritual ijazah Asma' Artho meyakini bahwa ijazah ini mempunyai argumentasi teologis yang jelas. Berbeda dengan pola pesugihan tidak islami yang selama ini marak di masyarakat. Selain itu, harga mahar yang diminta dalam proses ijazah ini tidak terlalu besar. Para tamu hanya perlu menyerahkan kelipatan uang yang di-asma-i. Hal ini yang membuat masyarakat yang mengikuti ritual ini cukup antusias mengikuti acara ijazah ini.

Ada banyak dalil yang menjadi dasar argumentasi ijazah Asma' Artho. Beberapa di antaranya bersumber dari dua kitab yang dikarang oleh Abū Hạ̄mid al-Ghazāli dalam kitab al-Awfāq, Abū Bakr Muhammad Shaṭā al-Dimyāțī dalam kitabnya I'ánat al-Tălibìn, dan Ma'rūf al-Karkhịi. Nama terakhir, al-Karkhī, mengatakan: barangsiapa membaca maulid Nabi pada beberapa dirham berlapis perak atau emas, kemudian dirham-dirham tersebut digabungkan dengan dirham yang lain, maka dirham-dirham tersebut akan mendapatkan berkah. Pemiliknya tidak akan mendapatkan kefakiran dan kekurangan harta, karena keberkahan maulid Nabi saw. Sedangkan Abū Hāamid alGhazālī dalam kitab al-Awfāq menyebutkan: "Barangsiapa menuliskan al-Bäsit_-salah satu nama Allah-dan digantungkan dalam rumah, maka ia akan didatangi rejeki setiap harinya. Adapun wirid yang dibaca pada fase ritual ijazah Asma' Artho terbagi menjadi tiga. Pada fase awal adalah membaca Maulid Barjanæi secara bersama-sama antara Kiai Hannan, santri, dan para tamu yang mengasmakkan uangnya.

\section{Daftar Rujukan}

'Arabī, Muhy al-Dīn b. Kashf al-Ma'nā 'an Sirr Asmā Allab al-Husnā. Beirut: Muassasat al-'Urwah al-Wuthqā, 2008.

'Arabīyah (al), Majma' al-Lughah. al-Mu'jam al-Wasịt. Kairo: Maktabah a-Shurūq al-Dawlīyah, Cet. Ke-4, 2005.

Abdau, Luzman. "Ritual Pesugihan di Gunung Kemungkus: Studi Deskriptif tentang Ritual di Gunung Kemungkus", Jurnal Program Studi Sosiologi, 2013.

Azizah, Nurul. "Persepsi Masyarakat, Tata Cara, dan Dampak Ritual Ngalap Berkah pada obyek wisata Gunung Kemukus Kabupaten

Sragen”. Skripsi--Universitas Muhammadiyah Surakarta, 2014.

Buku Alumni Pondok Pesantren Fathul Ulum Kwagean Pare, 2016.

Endraswara, Suwardi. Mistik Kejawen: Sinkretisme, Simbolisme, dan Sufisme dalam Budaya Spiritual Jawa. Yogyakarta: Narasi, 2003. 
Ghazālī (al), Abū Hāmid. al-Maqsad al-Asnā fì Sharḥ Asmā Allah alHusnā, Muhammad 'Uthmān Khisht (ed.). Kairo: Maktabat alQur'ān, 2001.

Hadi, Zamhari Prastyo. "Fenomena Pesugihan di Pesarean Gunung Kawi Kecamatan Wonosari Kabupaten Malang dan Muatan Pendidikannya”. Skripsi--Universitas Negeri Malang, 2014.

Handayani, Baiq Lily. "Transformasi Perilaku Keagamaan: Analisis terhadap Upaya Purifikasi Akidah Melalui Ruqyah Syariyah Pada Komunitas Muslim Jember", Jurnal Sosiologi Islam, Vol. 1, No. 2, Oktober 2011.

Haythamī (al), Ibn Hajar. al-Nímah al-Kubrā 'alā al-'Álam bi Mawlid Sayyid Walad Adam. t.t.: t.tp., t.th.

Huda, M. Syamsul. "Epistemologi Penyembuhan Kiai Tabib", Islamica: Jurnal Studi Keislaman, Vol. 8, No. 1, 2013.

Irawan, Yudha., Pinasti, V. Indah Sri., dan Lestari, Puji. "Fenomena Bersemedi di Tempat Petilasan Sekitar Gunung Srandil, Adipala, Cilacap, Jawa Tengah", E-Societas, Vol. 4, No. 6, 2015.

Jazāirī (al), Abī Bakr Jābir. Aysar al-Tafäsìr li Kalām al-'Aliyy al-Kabìr, Vol. 3. Kairo: Dār al-Salām li al-Ṭibā'ah wa al-Nashr wa alTawzī' wa al-Tarjamah, 1994.

'Abd al-Razzāq al-Kāshānī, Mu'jam Isțilāhạat al-Ṣūfìyah, 'Abd al-'Āl Shāhīn (ed.). Kairo: Dār al-Mannār, 1992.

Kishk, 'Abd al-Hamid. Asmā Allah al-Husnā: Ma'nāhā, Fadlubā, al-Du'ā' bihā. Kairo: al-Mukhtār al-Istāmī li al-Ṭab‘ wa al-Nashr wa alTawzi' ${ }^{-}$, t.th.

Koentjaraningrat. Sejarah Teori Antropologi. Jakarta: UI Press, 1987.

Maghribī (al), Ibn al-Ḥāj al-Tilimsānī. Shumūs al-Anwār wa Kunū̃ alAsrär al-Kubrā. t.t.: t.tp., t.th.

Miṣrī (al), Muḥammad b. Aḥmad al-Khațīb al-Sharbīnī. al-Sirāj alMunir fì al-T'ánah 'alà Ma'rifat ba'd Ma'āni Rabbunā al-Hakìm alKhabìr. Kairo: Maṭba'at Būlāq, t.th.

Najdī (al), Muḥammad Maḥmūd. al-Nabj al-Asmā fì Sharḥ Asmā Allah al-Husnā, Vol. 1. Kuwait: Maktabah al-Imām al-Dhahabī, t.th.

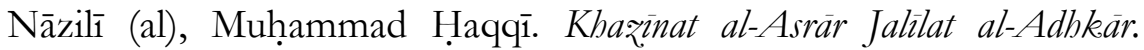
Mesir: Muṣtafā al-Bāb al-Halabī, t.th.

Novitasari, Rika Devi. "Ritual Ziarah Makam Pangeran Samudro di Gunung Kemukus Desa Pendem, Kecamatan Sumberlawang, Kabupaten Sragen”. Skripsi--Universitas Negeri Semarang, 2015. 
Penulis, Tim. Kumpulan Mujahadah Panitia Ijazah Kubro dan Asma' Artho 1434 H. t.t.: Pesantren Fathul Ulum Kwagean Krenceng Kepung Kediri, 2016.

Ruslani. Tabir Mistik: Alam Ghaib dan Perdukunan dalam Terang Sains dan Agama. Yogyakarta: Tinta, 2003.

Ṣābūnī (al), Muḥammad 'Alī. Șafwat al-Tafâsìr: Tafsìr li al-Qur'ān alKarim, Vol. 2. Libanon: Dār al-Fikr, 2001.

Sālājārī (al), Ishạāq al-Ḥāfiḍ. Durrat al'‘'A'dād fì 'Tlm Wad'i al-Awfāq. Kediri: PP Fathul Ulum, t.th.

Sālim, 'Abd al-Maqșūd Muḥammad. Fì Malakūt Allah ma'a Asmā Allah. Kairo: Shirkat al-Sharlā li al-Ṭab' wa al-Nashr wa alAdawāt al-Kitābīyah, 2003.

Shāfíī (al), Abū Bakr 'Uthmān b. Muḥammad Shațā al-Dimyāṭ̄. I'ānat al-Tälibin, Vol. 3. Surabaya: Maktabah al-Hidayah, t.th.

\section{Wawancara dan Observasi}

Abidin, Aziz (Santri Senior di Pondok Pesantren Fathul Ulum, Kwagean). Wawancara. 15 Juli 2016.

Hanafi (Wirausahawan di Gresik). Wawancara. Pare 26 Juni 2016.

Khozin, A. Mufti (Dosen Fakultas Syariah dan Hukum UIN Sunan Ampel). Wawancara. Pare 12 Mei 2017.

Maksum, Kiai Abdul Hannan. Wawancara. di Pare 23 Agustus 2016.

----. Wawancara. Pare 15 November 2015.

Munir, Misbahul (Santri Senior Pesantren Fathul Ulum Kwagean Pare). Wawancara. Pare 25 Juni 2017.

Syafii (Direktur Koperasi Tsuraya Pondok Pesantren Fathul Ulum Kwagean Pare Kediri). Wawancara. 12 November 2015.

Thayyib, Ahmad (Mahasiswa Program Studi Ekonomi Syariah UIN Maulana Malik Ibrahim Malang). Wawancara. Pare 27 Agustus 2016.

Observasi di Pasar Sepanjang Sidoarjo 15 Maret 2016.

Observasi di Pondok Pesantren Fathul Ulum di Kwagean Pare 24 Agustus 2016.

Observasi di Pondok Pesantren Fathul Ulum Kwagean Pare 18 November 2016.

Observasi di Pondok Pesantren Fathul Ulum Kwagean Pare Kediri, 3 Mei 2016. 